\title{
Закавказје
}

https://doi.org/10.18485/iipe_postsovjet.2021.ch13

\author{
Бранислав Милосављевић ${ }^{1}$ \\ Ненад Путник
}

\section{УЛОГА И ЗНАЧАЈ ТУРСКЕ У ОДНОСИМА ЈЕРМЕНИЈЕ И АЗЕРБЕЈЏАНА}

\begin{abstract}
Anстракт: Петнаест бивших совјетских република представља веома разнолику групу држава, са неравномерном економском развијеношћу, разноврсном демографском, етничком и верском структуром. У таквим околностима Турска, која географски припада и Европи и Азији, тражила је начин да оствари своје спољнополитичке приоритете и мењала начин вођења спољне политике на постсовјетском простору. Спор Јерменије са Турском је историјски и односи се на непризнавање геноцида над Јерменима од стране Турске у Првом светском рату. С друге стране, Азербејџан је по својим специфичностима умногоме сличан државама „азијским прагматичарима“ (Туркменистан, Таџикистан и Узбекистан) које су оријентисане на изградњу прагматичних односа са својим „великим суседима“, али је истовремено све више окренут према Турској. У сукобима око Нагорно-Карабаха, Турска жели да створи противтежу савезницима Јерменије, али и да учврсти статус регионалне силе.

Историјски посматрано, у односима на постсовјетском простору Турска је користила своју меку моћ, која се првенствено заснивала на националној култури, политичким вредностима, религији, економији, институцијама и спољној политици. Међутим, очигледно је да мека моћ у промењеним регионалним безбедносним околностима није била довољна, због чега је
\end{abstract}

\footnotetext{
${ }^{1}$ Бранислав Милосављевић, научни сарадник Института за стратегијска истраживања, Универзитет одбране, Београд, branislav.milosavljevic@mod.gov.rs

Ненад Путник, ванредни професор Факултета безбедности Универзитета у Београду, nputnik@fb.bg.ac.rs

Аутори у раду износе личне ставове, а не институције у којима су запослени.
} 
Турска поново почела да користи тврду моћ (војску) да ојача лидерску позицију. Пратећи доктрину „стратешке дубине“, под утицајем политике побољшања односа према суседима и неоосманизма, Турска је ишла путем заговарања западних политика према независности и утицају на регије Јужни Кавказ и Карабах у потрази за својим националним интересима.

Кључне речи: Турска, Нагорно-Карабах, мека моћ, оружани сукоб, употреба силе, стратешка дубина.

\section{Увод}

Почетком 1990-их година Централна Азија и Кавказ постају фокус турског интересовања, што уједно представља и заокрет у спољној политици. Наиме, за време Ататурка Турска није развијала сарадњу са турским и муслиманским становништвом ван државних граница. С друге стране, затвореност совјетског простора и осетљивост Москве по питању неруских националних мањина отежавали су комуникацију на простору Централне Азије и Кавказа. Међутим, распад Совјетског Савеза отворио је нове могућности и нове изазове за турску политику. Турски политичари, посебно бивши председник Тургут Озал, видели су Централну Азију као ново поље за ширење турског утицаја и јачање стратешке позиције Турске на западу. Иако су почетни напори Турске у Евроазији имали променљив успех, догађаји од 11. септембра 2001. године и рат против тероризма предвођен САД преобликовали су геополитику Евроазије. Средња Азија и Кавказ добили су нови геостратешки значај, посебно за САД, док су односи Русије и Турске претрпели значајне промене последњих година.

\section{Спољна политика Турске - кратак осврт}

Принципи турске спољне политике дефинисани су под утицајем Мустафе Кемала (Ататурк) након формирања Републике Турске 1923. године, а један од најважнијих је доследност политичке елите и њихово придржавање утврђених начела. Упркос многим променама и ревизијама, ови принципи су слични онима који су изнети током транзиције кемализма у Републици Турској. То је посебно важно у погледу Ататурковог односа према Западу, што се најбоље може видети у формулисању нових националних циљева Турске, и то: 
- Турска је земља која није ни експанзионистичка ни колонијална, већ која тежи развоју и унутрашњој снази у економском, индустријском, научном и војном подручју. Другим речима, настоји да оствари економску и технолошку моћ коју имају велике западне силе.

- поред постизања технолошке равноправности са Западом, Турска жели да буде призната као европска нација и да буде прихваћена у западном табору. ${ }^{2}$

Сходно томе, циљ Турске је пуноправно чланство у Европској заједници. Покушај приближавања Западу и економски проблеми утицали су да регионална политика Турске добије другоразредни значај у другој половини 1960-их година. Након тога је приступ Турске ревидиран и успостављени су економски односи са земљама региона. Распад Совјетског Савеза 1991. године и реструктурирање међународних односа, као резултат краја биполарног међународног система, довели су до промена у спољној политици многих држава, укључујући и Турску. Пре независности република Централне Азије и Кавказа, у периоду од преко 70 година, Русија је имала монополистичку позицију у регионалним односима. Међутим, наведени догађаји утицали су на појаву нових актера на овим просторима, укључујући и Турску. ${ }^{3}$

Победом Партије правде и развоја 2002. године и њеним доласком на власт 2003. године, дошло је до темељне промене спољне политике Турске у региону Кавказа. Најзначајнија промена односила се на претходни приступ мултилатерализму на регионалном и трансрегионалном нивоу. С тим у вези, Турска је покушала да диверсификује своје политичке партнере у региону уместо фокуса на западни центар - НАТО и америчку политику. ${ }^{4}$ Доласком Партије правде и развоја на власт, процес диверсификације спољне политике постепено се кретао према Блиском истоку, Африци и Јужном

\footnotetext{
2 Ferenc A. Vali, Bridge across the Bosporus: the foreign policy of Turkey, Johan Hopkins press, Baltimore, 1971, pp. 61-70.

${ }^{3}$ Aylin Gürzel, Turkey's Role as a Regional and Global Player and its Power Capacity: Turkey's Engagement with other Emerging States, Revista de Sociologia e Política, 22(50), 2014, pp. 95-105.

${ }^{4}$ Paula Sandrin, Turkish Foreign Policy after the End of Cold War From Securitizing to Desecuritizing Actor, Turkish Policy Quarterly (TPQ), 2009, p. 6, Internet: www.turkish policy.com/article/116/turkeyand-caucasus-at-the-edge-of-eu-andnatoenlargement
} 
Кавказу у намери да Турска постане активан учесник у региону. Конкретно, Јужни Кавказ и Карабах били су приоритет турске спољне политике. У том циљу, кључни аспект спољне политике нације подразумевао је побољшање односа са суседима. ${ }^{5}$ И унутрашњи политички простор је претрпео значајне промене у овом периоду, што је утицало на убрзано кретање Турске ка средњој сили у међународним односима. На почетку свог присуства на турској политичкој сцени, Партија правде и развоја покушала је да одржи стратешки однос са САД. ${ }^{6}$ У том контексту, Турска је као средња сила у настајању покушала да игра позитивну улогу, што је јасно назначио и тадашњи министар спољних послова Ахмет Давутоглу кроз формулисање приоритета у спољној политици.

Поред наведеног, значајно је и да су унутрашње политичке промене у Турској такође имале улогу трансформације спољне политике - од пуког стратешког савезника Запада до нове средње силе. Став Партије правде и развоја по питању унутрашњих односа био је ефикасан у одређивању њене спољне политике. С тим у вези, треба напоменути да током првог периода политичког учешћа Партије правде и развоја, Турска није могла да следи више независних спољнополитичких циљева због недостатка улоге и утицаја те партије у турској спољној политици, с обзиром на то да су војне снаге држале већи део моћи. Међутим, током другог периода, а нарочито након именовања Абдулаха Гулана за председника Турске и догађаја између војске и странке Правде и развоја, она је успела да добије подршку и подстакне јавно мњење да изрази своје ставове о спољнополитичком програму. Поред тога, мишљење је да је Турска од формирања велики део своје спољне политике посветила институционализацији односа са Европом и САД и да је деловала као флексибилан актер на Блиском истоку. ${ }^{8}$ Турска је са Ахмедом Давутоглуом, као главним креатором спољне

\footnotetext{
${ }^{5}$ Stephen F. Larrabee, Turkey as a U.S. Security Partner, Rand Corporation, Santa Monica, California 2008, p. 5

${ }^{6}$ Gareth H. Jenkins, Occasional Allies, Enduring Rivals: Turkey's Relations with Iran. Central Asia-Caucasus Institute \& Silk Road Studies Program, Washington, D. C., 2012, p. 26.

${ }^{7}$ Ahmet Davutoglu, Turkey's Foreign Policy Vision: An Assessment of 2007, Insight Turkey, Vol. 10 (1), 2008, p. 77.

${ }^{8}$ Steven A. Cook, US-Turkey relations: a new partnership, Council on Foreign Relations, Washington D. C., 2012, p. 37.
} 
политике, сматрала присуство и активну регионалну улогу најважнијим подручјем спољнополитичког деловања. Спољна политика странке Правде и развоја, заснована на идејама премијера Реџепа Тајипа Ердогана и председника Абдулаха Гула, може се представити кроз три водећа принципа и то:

- европеизација спољне политике као начин одржавања домаће и међународне легитимности државе,

- спровођење политике „нула проблема“ са суседима, односно стварање мирних услова за успостављање економских и основних интереса, посебно са исламским државама.

- вођење политике која успоставља потребну равнотежу између антиамеричких осећања, с једне стране, и тренутне потребе за америчком подршком, с друге стране.

Треба напоменути да је пре 2003. године спољна политика била далеко више прозападна и једнодимензионална, што је утицало да Турска формира велики део своје политике у правцу односа са Западом, посебно САД и Европском унијом. Доласком на власт Странке правде и развоја, турска спољна политика претворила се из једнодимензионалне у вишедимензионалну, прагматичну и интересно оријентисану на регионалном и међународном нивоу. Једна од важних промена димензије спољне политике била је обраћање веће пажње на периферне регионе и суседне државе ради повећања улоге и положаја Турске, укључујући Јужни Кавказ. ${ }^{9}$ Турска је у наредном кораку покушала да повећа сарадњу са Европском унијом у региону Јужног Кавказа, фокусирајући се на енергетску безбедност и решавање кризе у региону.

Турска је учествовала у формирању кохезивне стратегије Европске уније према источним суседима, а посебно Кавказу, како би убрзала чланство у Европској унији, те диверсификовала своје регионалне партнере, уједно покушавајући да сарађује са Европском унијом по питањима безбедности. На пољу безбедности, Турска је упркос критиковању неактивности Минске групе, повећала сарадњу са истом у решавању сукоба око НагорноКарабаха, а у циљу сарадње са европским политикама у оквиру Европске

\footnotetext{
${ }_{9}^{9}$ Pisheh Falahat Heshmatollah, Vahid Sharbati, Mohammad Mahdi Mozaffari, "Turkey's foreign policy in the South Caucasus and the Interests of Iran and Russia", Strategic Politic Articles Quarterly, Third Year, No. 12, 2016, p. 37.
} 
суседске политике и Програма сарадње Европске уније на Црном мору, који је Европа развила ради унапређења регионалне безбедности и економске сарадње и подршке консолидацији војних, политичких и безбедносних структура овог региона у Европи. ${ }^{10}$

\section{У троуглу односа на Јужном Кавказу}

Турска је у оквиру своје политике на Кавказу као приоритет за проширивање односа са Републиком Азербејџаном покушала да промовише стратешку сарадњу. Апсолутна подршка Турске Азербејџану током сукоба око Нагорно-Карабаха и рата између Јерменије и Азербејџана довели су до сукоба између Турске и Јерменије који имају дубоке историјске корене. Дакле, може се рећи да Турска сматра Кавказ територијом утицаја, али је међу земљама одвојеним од Совјетског Савеза Азербејџан ближи Турској у погледу језика, културе и етничке припадности. Током рата око Нагорно-Карабаха Турска је била савезник Азербејџана и 1992. године, након окупације дела Азербејџанске Републике од стране Јерменије, изразила спремност да нападне Јерменију, што је наишло на оштру реакцију САД и Русије, након чега је Турска само затворила своје границе према Јерменији. Наведени догађаји довели су у питање успостављање блиских односа између две државе од самог почетка, истовремено и Азербејџан је покушао да унапреди повезаност са западним државама зближавајући се са Турском. ${ }^{11}$

Поред неуспеха у посредовању, све веће наоружавање укључених страна и повремено кршење прекида ватре повећали су ризик ратних операција између две државе. Прекид ватре успостављен у мају 1994. године није поштован, па се стога сукоб око Нагорно-Карабаха не може назвати „тихим сукобом“. Сукоби који су се догодили 2014. године заправо су били крај релативне стабилности регије Карабах која је била доминантна

${ }^{10}$ Farhad Ataei, et al.: Foreign Policy of the Turkey Government for Justice and Development in the South Caucasus Region, Strategic Quarterly, Year 21, No. 63, 2012, p. 139.

${ }^{11}$ Moslem Karamzadi, Fahimeh Khansari Fard, Explaining the Contexts of the Convergence in the Relations between Iran and the Republic of Azerbaijan and its Challenges (from 1991 to 2014), Central Eurasian Studies, Volume 10, Issue 1, 2016, pp. 180-181. 
током протекле две деценије од 1994. године. Последњих година број кршења прекида ватре на позивним линијама се повећао. Поред тога, четвородневни рат из априла 2016. године, са више од 300 жртава, означио је врхунац крхкости мира у региону, ${ }^{12}$ као и повећану могућност започињања потпуног рата. Честа кршења прекида ватре на линијама сукоба, па чак и на међународним границама између Азербејџанске Републике и Јерменије, која за резултат имају цивилне и војне жртве, јављају се у ситуацији у којој је спорно подручје без мировних снага. Стране укључене у сукоб дуги низ година јачају војне способности и купују различиту и напредну борбену опрему, попут балистичких пројектила.

Табела бр. 1: Упоредни приказ буџетских издвајања за одбрану Јерменије и Азербејџана за период 2014-2019. године ${ }^{13}$

\begin{tabular}{|l|c|c|c|c|c|c|}
\hline & 2014 & 2015 & 2016 & 2017 & 2018 & 2019 \\
\hline Јерменија & 194 & 199 & 207 & 210 & 248 & 313 \\
\hline Азербејџан & 1,64 & 1,76 & 1,40 & 1,55 & 2,91 & 3,04 \\
\hline
\end{tabular}

Приходи остварени кроз енергетске ресурсе и јачање војне и економске моћи допринели су неравнотежи моћи у корист Азербејџана. Према Међународном институту за истраживање мира из Стокхолма, Република Азербејџан је између 2012. и 2016. године увезла оружја двадесет пута више од Јерменије. С тим у вези су и показатељи издвајања за одбрану који су такође на на страни Азербејџана (Табела бр. 1).

Поред наведеног, треба напоменути да Турска свој интерес на овим просторима има и у контексту енергетске безбедности, где покушава да оствари своје циљеве. Два главна нафтовода и гасовода изведена су уз подршку и укључивање турских интереса: Баку-Тбилиси-Џејхан (нафтовод) и Баку-Тбилиси-Ерзурум (гасовод). Према томе, Турска има вишестрану политику у региону Јужног Кавказа у вези са кризом Нагорно-Карабах и

${ }^{12}$ Council on Foreign Relations: Nagorno-Karabakh Conflict, 2018, доступно на: https://www.cfr.org/interactives/global-conflict-tracker?cid=ppc-Googlegrantconflict _tracker-031116\&gclid=CJi2Hfugq0wodchoDXw\#!/conflict/nagorno-karabakh-conflict

13 Izvor: Military Balance 2014-2019, The International Institute for Strategic Studies. 
њена перспектива превазилази оно што сматрамо једним од њених приступа. Данас се извоз Турске у Јерменију врши преко граница Грузије. Међутим, ако се постигне територијални интегритет Азербејџана, сигурно ће се остварити сигурно тржиште за Турску. Чак и Турска отварање граница на том подручју сматра проблемом границе између Јерменије и Азербејџана. Дакле, ови приступи се рефлектују у односима Турске и турској перспективи према Нагорно-Карабашкој кризи. Са овом азербејџанском геополитичком предношћу, Јерменија трпи губитке на три главна начина. Прво, Јерменија губи утицај у грузијско-јерменским односима, јер је за Грузију Азербејџан много профитабилнији и кориснији партнер. Док Грузија жели да смањи своју зависност од Русије, азербејџански пројекти цевовода пружају запослење, финансијску добит и енергију. Друго, три од четири суседа Јерменије постају богатији од ових енергетских партнерстава, повећавајући на тај начин финансијске разлике између Јерменије и њених суседа. Треће, Азербејџан остварује значајне предности са европским државама као неопходну алтернативу за енергетику, посебно док се западни и руски односи даље погоршавају. На тај начин Азербејџан добија већу вредност у односу на Јерменију. ${ }^{14}$

Иако турски и јерменски односи никада нису били добри, прилика за зближавање након независности Јерменије од СССР-а била је негирана када је Азербејџан, који је подржавала Турска, иницирао избијање сукоба око Нагорно-Карабаха. ${ }^{15}$ Иако је Турска признала Јерменију као независну државу 1991. године, затворила је границу са том земљом 1993. године у знак подршке Азербејџану због рата око Нагорно-Карабаха. Између 2008. и 2009. годинеТурска је покушала да нормализује односе са Јерменијом, али је та иницијатива пропала као последица снажног притиска Азербејџана, који је успео да услови напредак у нормализацији јерменскотурских односа предлозима за решавање сукоба око Нагорно-Карабаха. У

\footnotetext{
${ }^{14}$ Harris Gardiner, U.S. To Issue New Sanctions on Russia over Skripals'Poisoning, The New York Times, August 8, 2018, Internet: https://www.nytimes.com/2018/08/08/world /europe/sanctions-russia-poisoning-spy-trump-putin.html

${ }^{15}$ Fiona Hill, Kemal Kirişci, Andrew Moffatt, Armenia and Turkey: From Normalization to Reconciliation," Brookings Institution, 24 February 2015, Internet: https://www.broo kings.edu/articles/armenia-and-turkey-from-normalizationtoreconciliation/

https://sipri.org
} 
непосредној будућности нормализација односа између Јеревана и Анкаре не чини се могућом. Јерменци су повећали неповерење према Турској, док је домаћа подршка зближавању опала.

Иако нема назнака за побољшање турско-јерменских односа, мало је вероватно да ће турске снаге евентуално војно интервенисати и напасти Јерменију. Прво, Јерменија је потписница Организације за уговор о колективној безбедности (ОДКБ), чији је Русија гарант безбедности. Друго, САД и чланице НАТО сигурно нису заинтересоване за увлачење у ситни регионални сукоб, што би резултирало конфронтирањем са Русијом. Треће, Јерменија више није главни приоритетни турски спољнополитички проблем. Сиријски сукоб на турским границама, унутрашњи немири и поделе међу становништвом, забринутост због грчких односа око медитеранских острва и Кипра, као и због захлађења односа са САД, неки су од разлога који упућују на наведни закључак. Поред тога, Турска и Азербејџан су 2010. године потписали споразум о стратешком партнерству, што додатно отежава могућност успостављања дипломатских односа са Јерменијом. Војно партнерство са Азербејџаном ојачано је последњих година повећањем учесталости и капацитета заједничких војних вежби. ${ }^{16}$

Док Азербејџан стратешко партнерство види као противтежу рускојерменском војном партнерству, Турска га види као гаранцију за проток енергетских ресурса из басена Каспијског мора. Као што се примећивало у историји, географски положај Турске чинио ју је једним од најважнијих геостратешких места на свету, и још увек је. Данас Турска, уз остало, користи свој геостратешки положај за испоруку енергије са Блиског истока и Кавказа у Европу. ${ }^{17}$

\section{Турска мека моћ на Јужном Кавказу}

Након распада Совјетског Савеза у децембру 1991. године, Турска је била међу првим државама које су признале новоосноване државе на

${ }^{16}$ Zaur Shiriyev, Eka Tkeshelashvili, Mitat Celikpala, Institutionalizing a Trilateral Strategic Partnership: Azerbaijan, Georgia, Turkey, Policy Paper, Konrad Adenauer Stiftung, 2016, pp. 4-6.

${ }^{17}$ Anthony R. Branch, Armenia and the South Caucasus: A New Security Environment, The Quarterly Journal, 17, no. 2, 2018, pp. 55-57. 
постсовјетском простору, укључујући државе Јужног Кавказа - Јерменију, Азербејџан и Грузију. Азербејџан је од стране Турске признат 9. новембра 1991. године, а Јерменија и Грузија, заједно са републикама Централне Азије, 16. децембра 1991. године. Заинтересованост Турске за Кавказ и Централну Азију у целини није била искључиво везана за општу регионализацију њене спољне политике, већ се тицала и очекивања повећаног регионалног, а тиме и глобалног утицаја у међународним односима који су се брзо мењали. С тим у вези, Турска је намеравала да оствари већу улогу у овом региону у односу на конкуренте, Иран и Русију. Поред тога, актуелни тренутак је за Турску представљао и нове могућности за спровођење економских и енергетских интереса у овом региону. Поред наведених интереса, постојао је снажан националистички и етнички наратив, посебно у почетку, који је наглашавао поновно повезивање Турске са давно изгубљеним „турским светом“. Међутим, врло брзо су еуфорични осећаји и очекивања ослабили и замењени су реалнијим циљевима интензивирања односа Турске на овим просторима на свим нивоима. И поред тога, Турска је наставила са настојањем да постане што привлачнија за регионалне државе користећи инструменте меке моћи. Распад Совјетског Савеза и новостворени геополитички пејзаж представљали су за Турску нове могућности за изградњу утицаја. То је било посебно добродошло у време када се Турска борила са могућношћу њеног опадајућег стратешког значаја за САД и када је била одбијена за чланство у Европској унији 1989. године. Тадашњи државни министар Камран Инан тврдио је да „када се међународни контекст промени и систем блокова престане“, Турска је „хтела то или не, морала да прихвати да је регионална сила". Појава новог геополитичког простора је тако Турској пружила прилику да ову улогу игра као регионална сила. За владу тадашњег премијера Сулејмана Демирела (1991-1993) то је било за очекивати, јер је Турска била „у средишту новонастале политичке и економске структуре због свог јединственог културног, географског и историјског положаја". Према овом становишту, све ове промене додељивале су нове одговорности Турској. Такозвани „турски модел“, као секуларне и демократске државе засноване на економији слободног тржишта, виђен је као алтернатива иранским и руским моделима. Јасно је да је турски модел имао своја ограничења, али је препознат и промовисан као бољи од својих конкурената. Напокон, ове нове независне државе биле су у процесу транзиције и питање смера тог преласка било је од највеће 
важности. Према Сулејману Демирелу, „Турска је пример који је показао да ислам, демократија, људска права и тржишна економија могу коегзистирати у хармонији“. ${ }^{18}$

Такво представљање Турске подржале су и промовисале САД првенствено као одраз забринутости због супарничких модела, а амерички државни секретар Џејмс Бејкер (James Baker) je 1992. године позвао ове државе да усвоје „турски модел секуларизма, либералне демократије и тржишне економије“. ${ }^{19}$ С друге стране, успостављени „турски модел“ имао је своје присталице у региону, при чему је други председник Азербејџана Абулаз Елчибеј, који је био на власти од јуна 1992. до јуна 1993. године, снажно подржавао као модел за Азербејџан. ${ }^{20}$ Поред Елчибејевог Азербејџанског народног фронта (АПФ), странка Мусават (Азербејџан) и друге странке у различитим државама, попут странке Азат (Казахстан) и Ерк и Бирлик (Узбекистан) такође су подржале „турски модел“ и интензивирале односе са Турском. ${ }^{21}$ Други аспект привлачности Турске заснивао се на њеној способности да помогне новим независним државама да успоставе односе са остатком света. Премијер Демирел је на конференцији за новинаре, у марту 1992. године, изјавио да Турска представља „културно средиште и историјски магнет" за нове независне државе уз тврдњу: „Једноставно верујемо да можемо помоћи овим републикама у њиховом давно започетом покушају интеграције са светом“.22

У почетним годинама независности, државе региона биле су жељне да достигну ниво регионалног и глобалног утицаја и моћи Турске. У августу 1992. азербејџански министар спољних послова Тофик Гасимов је изјавио:

${ }^{18}$ Meliha Benli Altunışık, Turkey's Soft Power in a Comparative Context: The South Caucasus and the Middle East, In: Mehran Kamrava (ed), The Great Game in West Asia, Oxford University Press, 2016, pp. 163-164.

${ }^{19}$ Gareth Winrow, "Turkish Policy in Central Asia”, in Alan Makovsky, Sabri Sayarı (eds), Turkey's New World: Changing Dynamics in Turkish Foreign Policy, Washington Institute of Near East Policy, Washington, D. C. 2000, p. 117.

${ }^{20}$ Stephan F. Larrabee, Ian O. Lesser, Turkish Foreign Policy in an Age of Uncertainty: RAND Corporation, Santa Monica, CA 2003, p. 104.

${ }^{21}$ Shireen Hunter, "Turkey, Central Asia and the Caucasus: Ten Years after Independence," Southeast European and Black Sea Studies, Vol. 1, No. 2, 2001, p. 8.

22 Philip Robins, Suits and Uniforms: Turkish Foreign Policy since the Cold War, Hurst \& Co., London, 2003, p. 282. 
„Желимо помоћ Турске у успостављању веза са светом“. ${ }^{23}$ У ствари, с обзиром на њихове суседе, Турска је била логичан избор за њихов циљ. Користећи своје институционално чланство у неколико западних институција, попут НАТО и Савета Европе, Турска се представила као атрактиван партнер државама Јужног Кавказа и Централне Азије и играла активну улогу у успостављању веза између ових држава и Запада. Нарочито током 1990-их, ангажовање Турске на Јужном Кавказу било је усмерено на Азербејџан и Грузију. Убрзо након проглашења независности Јерменије и турског почетног признавања нове државе, односи су постали затегнути. Јерменија је одбила да призна границу повучену и договорену споразумом у Гумру 1920. године, између Турске и бивше Јерменске Републике. Граница је касније потврђена Каршким уговором између Совјетског Савеза и Турске 1921. године, што је умногоме спречило успостављање формалних дипломатских односа. Убрзо је деловање јерменске дијаспоре, а потом и захтев Јерменије да Турска призна депортацију и геноцид Јермена током Првог светског рата под Османским царством створило нове тензије. Међутим, сукоби у Нагорно-Карабаху између Јерменије и Азербејџана представљали су додатно ограничење за нормализацију односа. Иако је почетком марта 1993. године, када је сукоб први пут избио, Турска покренула озбиљан билатерални покушај посредовања у јерменскоазербејџанском сукобу, јерменска инвазија на територију Азербејџана довела је до затварања границе Турске са Јерменијом 1993. године. ${ }^{24}$

Азербејџан је, с друге стране, постао поборник турске политике у Јужном Кавказу, стварајући свој приступ у идејном контексту историјских, културних и језичких веза, због чега је и Турска своје економске и стратешке интересе тражила у односима са Азербејџаном. Грузија је, такође, постала земља са којом је Турска интензивно остваривала сарадњу, а две земље су развиле блиске односе који су били прилично неочекивани. С тим у вези, евидентан је интерес Тбилисија да се удаљи од Русије и повеже са западним институцијама, а уз то су и заједнички економски и енергетски интереси били од пресудног значаја за повезивање две државе. Другим

${ }^{23}$ Anthony Hyman, Moving Out of Moscow's Orbit: The Outlook for Central Asia, International Affairs, Vol. 69, No. 2, 1993, p. 299.

24 Philip Robins, Suits and Uniforms: Turkish Foreign Policy since the Cold War, Hurst \& Co., London, 2003, p. 291. 
речима, мека моћ Турске остваривала се углавном према овим двема земљама у региону. Већ 1991. године остварено је неколико посета турских званичника на високом нивоу просторима Централне Азије и Јужног Кавказа. У једној таквој посети у априлу-мају 1992. године, тадашњи премијер Демирел представио је велике амбиције и визије Турске у погледу овог региона. Најавио је 1,1 милијарду америчких долара кредита и помоћи, охрабрио ове државе да изађу из зоне рубље, обећао да ће пружити војну обуку и предложио изградњу нафтовода и гасовода за транспорт енергената кроз Турску. Поред тога, подстакао је ове државе да пређу на латинично писмо и позвао на успостављање директних саобраћајних и комуникационих веза, укључујући ТВ преносе, те најавио директне авио-летове. То је, између осталог, указивало на ниво очекивања која је имала Турска. Иако су се ови пројекти у то време чинили нереалним, скоро сви су реализовани. Интензивирање образовних веза са државама Јужног Кавказа и Централне Азије постало је ослонац турске спољне политике на овим просторима. Образовна политика имала је два елемента, при чему је први био давање стипендија студентима на основним и постдипломским студијама за студирање у Турској, а други оснивање школа на различитим нивоима у овим земљама. Турска је прво покренула велики пројекат размене студената 1991. године. Министарство националног образовања основало је Одељење за прекогранично образовање и управљање новим програмом стипендирања. Програм је започет у академској 1992/1993. години и у почетку је понудио 7.000 високошколских и 3.000 средњошколских стипендија студентима из „турских земаља“, укључујући Азербејџан. Од 2010. године, укупан број универзитетских студената у Турској из „турских република“ и турских заједница био је 6.294, при чему је у периоду 1992. до 1998. године 2.570 азербејџанских студената добило стипендије. ${ }^{25}$

Успостављање културних контаката са регионом сматрано је кључним за ревитализацију веза и обнову културних мостова. Турско Министарство културе покренуло је пројекат који је довео до успостављања Турске заједничке управе за културу и уметност (Turkish Culture and Arts Joint

\footnotetext{
${ }^{25}$ Akçal Pınarı, Cennet Engin-Demir, "Turkey's Educational Policies in Central Asia and Caucasia: Perceptions of Policy Makers and Experts," International Journal of Educational Development, No. 32, 2012, p. 13.
} 
Administration - TÜRKSOY) у јулу 1993. године. Министарство националног образовања покренуло је пројекат преправљања књига из историје и књижевности у новембру 1992. године. Поред тога, на иницијативу Турске, састанци шефова држава турског говорног подручја почели су да се одржавају од 1992. године и институционализовани су успостављањем Савета за сарадњу држава са турским говорним језиком (Турског савета) у октобру 2009. године. Секретаријат Савета је основан у Истанбулу. Државна турска организација за емитовање (ТРТ) започела је своје прво транснационално емитовање и покренула пројекат Евроазија (Аврасиа) у априлу 1992. године. Управа за верска питања и њена Фондација за верска питања били су веома активни од почетка, при чему је њихов активизам на Јужном Кавказу био прилично занимљив, с обзиром на то да су већина становништва Азербејџана муслимани, а Грузије православци. Управа за верска питања (Diianet) била је активна у изградњи и поправци џамија, подржавајући верско образовање кроз оснивање школа, школовање проповедника и слање верског материјала. У Азербејџану је основана теолошка школа, заједно са једном средњом школом и осам нових џамија којима је управљала Управа за верска питања. ${ }^{26}$ Као одговор на трансформације на Јужном Кавказу и у Централној Азији, Турска агенција за сарадњу и координацију (ТИКА) основана је у јануару 1992. године. Циљ организације у почетку био је да одговори на потребе реструктурирања, прилагођавања и развоја „турских“ република, али је пружила помоћ и Грузији (Табела бр. 2).

Табела бр.2: Упоредни приказ Турске званичне развојне помоћи Азербејџану и Грузији у периоду 2014-2019. године (у милионима долара $)^{27}$

\begin{tabular}{|l|r|r|r|r|r|r|}
\hline & 2014 & $\mathbf{2 0 1 5}$ & $\mathbf{2 0 1 6}$ & $\mathbf{2 0 1 7}$ & $\mathbf{2 0 1 8}$ & $\mathbf{2 0 1 9}$ \\
\hline Азербејџан & 36,6 & 8,76 & 14,24 & 10,29 & 3,70 & 6,01 \\
\hline Грузија & 6,1 & 3,69 & 5,31 & 5,86 & 2,45 & 4,74 \\
\hline
\end{tabular}

${ }^{26}$ Jerzy Rohozinski, "Azerbaijan and Turkey: The Light and Shade of 'Turkish' brotherhood", in: Turcja after the Start of Negotiations with the European Union - Foreign Relations and the Domestic Situation, CES Report, Warsaw, 2008, p. 14.

${ }^{27}$ Turkish Development Assistance Report 2014-2019, Internet, https://www.tika.gov.tr/ en/publication/list/turkish_development_assistance_reports-24 
У том контексту, Турска је понудила програме обуке и семинаре владиним званичницима у овим државама. Један од програма био је усмерен на обуку дипломата са Јужног Кавказа и Централне Азије, који је започет 1992. године. Програм се и данас реализује на проширеном географском простору, укључујући Блиски исток. Између 1992. и 1998. године укупно је обучено 297 дипломата, а поред тога су постојали семинари за администрацију, менаџере банака, омладинске лидере, ректоре универзитета, новинске агенције, наставнике и друго особље из министарстава образовања. ${ }^{28}$ Укупан број полазника који су учествовали на овим семинарима између 1995. и 1999. године био је 910.

Турска је поздравила појаву „турског света“ на Јужном Кавказу и у Централној Азији, и искористила је могућности које су се појавиле у те две регије да консолидује свој међународни статус представљајући се као мост ка спољном свету. Да би се постигли дефинисани циљеви, развијено је неколико политика и успостављене су одређене институције. У таквим околностима сасвим је логично питање да ли је Турској мека моћ помогла да постигне циљеве и повећа моћ и оствари успешан утицај? На крају деценије тај успех је био половичан, с обзиром на то да је постало јасно да је почетна еуфорија Турске била неутемељена и да су државе примаоци увиделе да су њени дискурси били покровитељски. У неколико наврата лидери ових земаља изјавили су да су ослобођени совјетске власти и да не траже другог „великог брата“. Границе турског оптимизма биле су на проби на првом турском самиту одржаном у Анталији, у октобру 1992. године, када је неколико регионалних држава изразило оклевање да настави са амбициозним плановима као што је успостављање заједничког тржишта. Русија је сасвим јасно изразила неслагање са таквим скупом, а државе Јужног Кавказа и Централне Азије биле су подједнако осетљиве на забринутости Русије и нису желеле да поспешују антагонизам у међудржавним односима. ${ }^{29}$

${ }^{28}$ Pinar Akçalı, Demir Engin, "Turkey's Educational Policies in Central Asia and Caucasia Perceptions of policy makers and experts", International Journal of Educational Development, Volume 32, Issue 1, 2012, p. 13.

${ }^{29}$ Yasemin Celik, Contemporary Turkish Foreign Policy Westport, CT: Greenwood Publishing, 1999, pp. 127-128. 
Турска је убрзо морала да се помири са реалношћу повратка Русије у ове регионе, а идеја да буде модел управљања углавном је одбачена. Убрзо је постало јасно да државе региона неће усвојити исламску државу нити следити „турски модел“. Иако је та идеја с времена на време излазила на површину (на пример, 2000. године тадашњи министар спољних послова Исмаил Цем рекао је у интервју да је „Турска парадигма модернизације за евроазијске народе који теже социјалним променама у плуралистичкој и секуларној демократији“), ${ }^{30}$ углавном је остављена по страни када је и сама Турска почела да следи своје интересе, уместо да се укључује у оно што се данас сматра унутрашњим пословима ових држава. Значајна улога Турске у тим земљама као мосту према спољном свету била је истакнута почетком 1990-их, али је почела да се смањује како су те земље успоставиле сопствене везе. У погледу Јужног Кавказа, спољнополитички активизам Турске и покушаји да игра конструктивне улоге били су лимитирани проблемима са Јерменијом. Такође, ограничавајући фактор је био и утицај Азербејџана на позицију Турске у сукобу око Нагорно-Карабаха. Пример за то је неуспели предлог Пакта стабилности за Јужни Кавказ који није остварен 2000. године. Међутим, Турска је успела да одржи блиске односе са Азербејџаном и Грузијом. Контакт са Грузијом сматран је „узорним“ и показао је да утицај Турске превазилази етничке и (или) верске везе. Наиме, Турска је у великој мери помогла у тежњи ових земаља за институционалним везама са неколико међународних организација. Генерално, Турска је могла да се постави као важан политички и економски актер у региону током 1990-их и успоставила је блиске контакте са становништвом кроз ширење мрежа политика и институција. Када је Партија правде и развоја (АКП) дошла на власт, то је означило и континуитет и промене у интеракцији Турске са Јужним Кавказом. ${ }^{31}$ Наставио се тренд ка реалнијим политикама, при чему су истовремено Јужни Кавказ и Централна Азија престали да буду приоритетни регион за владајућу Партију правде и развоја. Пажња је скренута на Блиски исток, са великим очекивањима која се нису толико разликовала од оних која су у ранијем периоду постојала према Јужном Кавказу и Централној Азији. На

30 İsmail Cem, Turkey in the New Century, Rustem Publishing, Nicosia, 2001, p. 61.

${ }^{31}$ Videti: Balcı Bayram, "Strengths and Constraints of Turkish Policy in the South Caucasus", Insight Turkey, Vol. 16, No. 2, 2014. 
Јужном Кавказу су Азербејџан и Грузија углавном остали важни партнери Турске. Међутим, велика промена односила се на односе са Јерменијом. Као део своје политике „нула проблема са суседима“, турска владајућа партија активно је тежила нормализацији односа са Јерменијом. У међувремену су чак потписана два протокола, Протокол о успостављању дипломатских односа и Протокол о развоју односа, што је остварено под швајцарским посредовањем за нормализацију односа у Цириху у октобру 2009. године. Међутим, тај процес је заустављен и протоколи су остали нератификовани у националним парламентима. ${ }^{32}$ За Турску је главни узрок неуспеха у спровођењу протокола био Азербејџан, који је био незадовољан могућношћу нормализације односа између Јерменије и Турске пре решавања спора око Нагорно-Карабаха. Баку је тада покренуо моћну кампању јавне дипломатије против протокола, доводећи турску владу у веома неугодан положај. Током владавине Партије правде и развоја, настављене су претходне политике за интензивирање образовних, културних и верских веза, као и друге помоћи. Нарочито је у погледу програма образовања и помоћи дошло до значајног повећања и у погледу ресурса и уопштег обима.

Прикључивши се Азербејџану у сукобу око Нагорно-Карабаха, Турска је пре свега тежила промени тренутног статуса у региону. Анкара је првенствено имала за циљ да себи обезбеди место за столом за којим ће се преговарати о будућности и решењу сукоба између Јерменије и Азербејџана, при чему би као пример требало да послужи сиријски сценарио. Из тих разлога Турска жели да преговара са Русијом на Јужном Кавказу, по могућности без западних актера. Такви планови Анкаре нису незанимљиви за Москву. Међутим, због сложености турско-јерменских односа постоји ризик да Јерменија и Турска могу постати потенцијалне противничке стране у овом сукобу, а не Јерменија и Азербејџан. Турски циљеви у сукобу око Нагорно-Карабаха су двојаки. С једне стране, уз подршку Азербејџана жели се стварање противтеже савезницима Јерменије. Из њене перспективе, то су три лидера Минске групе - САД, Француска и Русија. С друге стране, Турска жели да учврсти свој статус

\footnotetext{
${ }^{32}$ Aybars Görgülü, “The Litmus Test for Turkey's New Foreign Policy: The Historical Rapprochement with Armenia," in: Kerem Öktem, et al. (eds), Another Empire? A Decade of Turkey's Foreign Policy Under the Justice and Development Party, İstanbul: Bilgi University Press, 2012, pp. 283-284.
} 
регионалне силе учешћем у процесу преговора. Чињеница да је Анкара постала најближи савезник Бакуа може се у великој мери приписати напорима Азербејџана. Често цитирану изјаву у Турској, која се односи на Азербејџан - „једна нација, две државе“, сковао је бивши азербејџански председник Хајдар Алијев деведесетих година прошлог века. После одвајања од Совјетског Савеза Азербејџан је могао да рачуна на подршку Турске, не само у интеграцији у међународне организације већ и у успостављању сопствених оружаних снага након првог рата око НагорноКарабаха. ${ }^{33}$

Правни оквир за учешће Турске у тренутном сукобу пружа Споразум о стратешком партнерству и узајамној помоћи који су Анкара и Баку закључили 2010. године. Поред заједничких војних вежби уговор предвиђа да ће потписници помагати једни другима „свим могућим средствима“ у случају „агресије“ треће стране. Подстицај за продубљивање сарадње Анкаре и Бакуа на војном пољу дали су слични споразуми Русије и Јерменије. Већ 2010. закључивање споразума о партнерству између Анкаре и Бакуа виђено је као знак незадовољства Азербејџана Минском групом. Док Баку, уз помоћ Анкаре, покушава да промени status quo у сукобу са Јерменијом, амбиције Турске превазилазе Нагорно-Карабах. У марту 2020. године, турски министар одбране Хулуси Акар прогласио је претензије своје земље на већи утицај на Блиском истоку, Кавказу, Источном Медитерану, Балкану и Егеју. Према Акару, под вођством Реџепа Тајипа Ердогана, Турска је постала „субјект на међународној сцени“. На Јужном Кавказу Ердоган је, такође, опредељен да Турској обезбеди „заслужено место у светском поретку“ уз САД и Русију.

\section{Турска у последњем сукобу у Нагорно-Карабаху}

Други рат око Нагорно-Карабаха између Јерменије и Азербејџана завршио се 10. новембра 2020. године. Војна победа Азербејџана се објашњава разним факторима, а два фактора посматрачи сматрају „чаробним мецима“: улога беспилотних летелица из Турске и Израела и

${ }^{33}$ Daria Isachenko, Turkey-Russia Partnership in the War over Nagorno-Karabakh, German Institute for International and Security Affairs, Berlin, 2020, pp. 1-3. 
саветодавна улога турског вишег војног особља у оперативним плановима и команди Азербејџана. Али, иако су изузетно важни, ови фактори не објашњавају довољно исход сукоба. Постоји још један значајан фактор. Убрзо након распада Совјетског Савеза, Турска је започела изградњу азербејџанских оружаних снага, заједно са снагама још неколико бивших совјетских република. Недавна победа Азербејџана против Јерменије резултат је овог тридесетогодишњег напора. Као резултат овог непрекидног процеса образовања и обуке, азербејџанска војска је развила снажне људске ресурсе, као и ефикасне командне вештине. Током три деценије, традиција строге дисциплине и послушности у турским оружаним снагама превладала је некадашњи совјетски утицај на азербејџанску војску, а процес образовања и обуке који су водиле турске копнене снаге спровеле су и морнарица и ваздухопловство. Турски капацитет за изградњу војске био је очигледно један од водећих фактора који је допринео победи Азербејџана у Другом нагорно-карабашком рату, што је најважнија разлика између сукоба 2020. и Првог нагорно-карабашког рата. Док се први сукоб водио између две војске са совјетским војним наслеђем, други се одвијао између војске која је још увек живела у претходном веку наспрам модерне војске са западним стандардима. Улога коју је Турска играла у Азербејџану показује не само њен капацитет за изградњу војске, већ и њен потенцијал да даље доприноси трансатлантском савезу у свом региону и шире. ${ }^{34}$

Турска је у периоду од 2011. до 2020. године учествовала са 2,9\% у азербејџанском увозу оружја, при чему су се турске испоруке у овом периоду првенствено односиле на оклопна патролна возила, ракетну артиљерију, ракете и наоружане беспилотне летелице. Наоружане беспилотне летелице, које су испоручене непосредно пре рата 2020. године, укључивале су најмање пет беспилотних летелица Баирактар-ТБ2 наоружаних навођеним бомбама. Употреба ових беспилотних летелица током рата привукла је значајну међународну пажњу. Иако је нејасно да ли је и у којој мери Азербејџан користио остало наоружање које је Турска испоручила у рату 2020. године, неки извештаји сугеришу да је то био случај.

\footnotetext{
${ }^{34}$ Haldun Yalçınkaya, Turkey's Overlooked Role in the Second Nagorno-Karabakh War, German Marshall Fund of the United States, January 21, 2021, Internet: https://www.gmfus.org/publications/turkeys-overlooked-role-second-nagornokarabakh-war
} 
На пример, извештаји указују да су вишецевни ракетни бацачи ТРГ-300, испоручени од Турске, били смештени на положајима од стратешког значаја за офанзиву Азербејџана у Нагорно-Карабаху 2020. године. Чини се да су трансфери оружја Турске Азербејџану повезани не само са снажним економским везама и културним везама две земље, већ и са ширим спољнополитичким интересима Турске. Јачајући односе са Азербејџаном, чини се да Турска такође шири своје политичко присуство на Јужном Кавказу - нарочито у конкуренцији са Русијом, која је тренутно доминантна сила у региону 35 .

Најважнији ослонац Азербејџана било је модерно и тешко наоружање и опрема купљена од Русије, Турске и Израела у замену за ресурсе са богатих нафтних поља земље. Азербејџан је у овом процесу обновио комуникациони и сателитски систем војске. У том контексту, турска компанија за одбрамбену индустрију АСЕЛСАН (Војна електронска индустрија) играла је важну улогу у стварању неке врсте паметне муниције коју је развио Азербејџан и развијању репелента за дронове. Рокетсан је такође постигао договор 2010. године о продаји навођених артиљеријских ракета и ракетних система великог домета Азербејџану. У арсеналу азербејџанских оружаних снага могу се видети и ракетни системи великог домета и ракета Каплан, за које је планирана испорука према овом споразуму. У азербејџанској штампи је наведено да је 20 лансера балистичких ракета Каплан домета 120 километара извезено у Азербејџан након уласка у инвентар Турске 2017. године. Овај извоз се повећао још више од 2011. до 2016. године, а 26. јуна 2019. године, на годишњицу успостављања азербејџанске војске, председник Алијев је изјавио да су се „наши војни издаци повећали 15 пута од 2003. године“, при чему је војни материјал увезен из Турске или произведен у сарадњи са Турском, што укључује и напредно оружје и пушке.

У видео запису објављеном на званичном каналу Министарства одбране Азербејџана, од 2. маја 2020. године, видело се да је ракетни систем под називом Каплан, увезен из Турске, намењен не само за

\footnotetext{
${ }^{35}$ Pieter D. Wezeman, Alexandra Kuimov, Jordan Smith, Arms transfers to conflict zones: The case of Nagorno-Karabakh, Stockholm International Peace, 30 April 2021, Internet: https://www.sipri.org/commentary/topical-backgrounder/2021/arms-transfers-conflictzones-case-nagorno-karabakh
} 
Нагорно-Карабах већ и за Нахчиван, где се налазе и ракетни бацачи Касирга и Сакариа. Године 2019. објављено је да је Азербејџан такође заинтересован за беспилотне летелице турске производње и наоружане беспилотне летелице. Након сукоба у регији Товуз на азербејџанскојерменској граници, председник одбрамбене индустрије Исмаил Демир рекао је: „Наша одбрамбена индустрија је увек на располагању Азербејџану са свим својим искуством, технологијом и могућностима, од наших дронова, преко наше муниције и ракета, до наших система за електронско ратовање“. ${ }^{36}$ Турска је увек подржавала Азербејџан на основу културних веза и заједничких геополитичких тежњи. Међутим, у последње време, како је Анкара постајала све упорнија у деловању на Блиском истоку и Медитерану, њена политика према региону Нагорно-Карабаха довела је до тога да јој се Баку још више приближи.

\section{Закључак}

Сукоб око Нагорно-Карабаха била је прилика за Турску у време када су главне светске силе ометене унутрашњим питањима, продуженом пандемијом COVID-19 и економским проблемима. У тим околностима Турска се отворено залаже за промену status quo око Нагорно-Карабаха. По мишљењу Анкаре, Француска, САД и Русија деценијама су предводиле напоре за међународно посредовање без икаквог опипљивог резултата, јер је Јереван задржао контролу над енклавом и суседним територијама. Због тога није чудо да су лидери Француске, Русије и САД заједно позвали Јерменију и Азербејџан да постигну примирје на спорној територији Нагорно-Карабаха, док је Ердоган критиковао Минску групу.

Повећана подршка Турске Азербејџану била је видљива у рату између Азербејџана и Јерменије од септембра до октобра 2020. године: наоружани дронови турске производње су предводили нападе Азербејџана, а Анкара је вероватно пружала инфраструктуру и подршку за то оружје. Према Ердогану, подршка Анкаре Азербејџану била је део турске

\footnotetext{
${ }^{36}$ Ece Göksedef, Nagorno-Karabakh: How did Turkey play a role in the development of Azerbaijan's military capacity?, BBC, October 2, 2020, Internet: https://www.bbc.com/ turkce/haberler-turkiye-54379105
} 
потраге за „заслуженим местом у светском поретку“. То се уклапа у укупни образац спољне политике земље на Блиском истоку и Медитерану. Анкара сматра да ће, упркос разликама око Нагорно-Карабаха, Турска и Русија моћи да пронађу трајно решење сукоба. Један од важних аспеката биће турско учешће у мировном процесу. Турско руководство је наговестило такав сценарио када је турски министар спољних послова Мевлут Чавушоглу најавио спремност Анкаре да ради са Москвом на решавању јерменско-азербејџанског сукоба. Сарадња помешана са интензивном конкуренцијом била је обележје руско-турских односа у последњих неколико година. Као што показује случај северне Сирије, они су у стању да дођу до трајних решења упркос тензијама између њих. Шире гледано, сарађивали су у маргинализацији западних сила и у Сирији и у Либији, а сличан тренд се јавља и око Нагорно-Карабаха.

Први знаци појачане турске улоге у сукобу око Нагорно-Карабаха били су уочљиви у јулу 2020. године, када је Анкара необично жустро реаговала на избијање јерменско-азербејџанских борби које су биле наговештавај рата до кога је убрзо дошло. Анкара је обећала да ће убрзати испоруку дронова турске производње Азербејџану, који су касније одиграли значајну улогу у азербејџанској победи. Чини се да је Турска учествовала и у планирању и припреми за борбе 27. септембра 2020. године. Наиме, више извора је известило да је Турска већ почела да регрутује сиријске побуњеничке борце за борбу у Нагорно-Карабаху почетком септембра. Иако су ови милицијски борци морали бити од ограниченог значаја у оном што је, на крају крајева, био рат између две конвенционалне војске, Сиријци су можда били распоређени из разлога одвраћања или као елемент подршке за операторе беспилотних летелица и остало турско особље. Вреди напоменути да је Турска раније користила сличне тактике у сирији и Либији, укључујући комбиновано распоређивање сиријских ловаца и турских дронова.

\section{Библиографија}

Altunışık Benli, Meliha, Turkey's Soft Power in a Comparative Context: The South Caucasus and the Middle East, In: Kamrava Mehran (ed), The Great Game in West Asia, Oxford University Press, 2016. 
Ataei, Farhad, et al.: Foreign Policy of the Turkey Government for Justice and Development in the South Caucasus Region, Strategic Quarterly, Year 21, No. 63, 2012.

Akçalı, Pınar, Engin-Demir, Cennet, Turkey's Educational Policies in Central Asia and Caucasia: Perceptions of Policy Makers and Experts," International Journal of Educational Development, No. 32, 2012.

Akçalı, Pınar, Engin-Demir, Cennet, Turkey's Educational Policies in Central Asia and Caucasia Perceptions of policy makers and experts, International Journal of Educational Development, Volume 32, Issue 1, 2012.

Balcı, Bayram, "Strengths and Constraints of Turkish Policy in the South Caucasus," Insight Turkey, Vol.16, No. 2, 2014 Council on Foreign Relations: Nagorno-Karabakh Conflict, 2018, Internet:https://www.cfr.org/interactives /global-conflict-tracker?cid=ppc-Googlegrantconflict_tracker-031116\& gclid=CJi2HfugqOwodchoDXw\#!/conflict/nagorno-karabakh-conflict

Branch, Anthony R., Armenia and the South Caucasus: A New Security Environment, The Quarterly Journal, 17, no. 2, 2018.

Cem, İsmail, Turkey in the New Century, Rustem Publishing, Nicosia, 2001.

Cook, Steven A., US-Turkey relations: a new partnership, Council on Foreign Relations, Washington D. C., 2012.

Celik, Yasemin, Contemporary Turkish Foreign Policy Westport, CT: Greenwood Publishing, 1999.

Davutoglu, Ahmet, Turkey's Foreign Policy Vision: An Assessment of 2007, Insight Turkey, Vol. 10 (1), 2008.

Ece, Göksedef, Nagorno-Karabakh: How did Turkey play a role in the development of Azerbaijan's military capacity?, BBC, October 2, 2020, Internet: https://www.bbc.com/turkce/haberler-turkiye-54379105

Ferenc, Vali A., Bridge across the Bosporus: the foreign policy of Turkey, Johan Hopkins press, Baltimore, 1971.

Gardiner, Harris, U.S. To Issue New Sanctions on Russia over Skripals'Poisoning, The New York Times, August 8, 2018, Internet: https://www.nytimes.com/ 2018/08/08/world/europe/sanctions-russia-poisoning-spy-trumpputin.html 
Gürzel, Aylin, Turkey's Role as a Regional and Global Player and its Power Capacity: Turkey's Engagement with other Emerging States, Revista de Sociologia e Política, 22(50), 2014.

Görgülü, Aybars, "The Litmus Test for Turkey's New Foreign Policy: The Historical Rapprochement with Armenia", in Kerem Öktem et al. (eds), Another Empire? A Decade of Turkey's Foreign Policy Under the Justice and Development Party istanbul: Bilgi University Press, 2012.

Hyman, Anthony, "Moving Out of Moscow's Orbit: The Outlook for Central Asia", International Affairs, Vol. 69, No. 2, 1993.

Heshmatollah, Falahat Pisheh, Sharbati, Vahid, Mohammad Mozaffari, Mahdi, "Turkey's foreign policy in the South Caucasus and the Interests of Iran and Russia", Strategic Politic Articles Quarterly, Third Year, No. 12, 2016.

Hill, Fiona, Kirişci, Kemal, Moffatt, Andrew, "Armenia and Turkey: From Normalization to Reconciliation," Brookings Institution, 24 February 2015, Internet: https://www.brookings.edu/articles/armenia-and-turkey-fromnormalizationtoreconciliation/ https://sipri.org

Hunter, Shireen, "Turkey, Central Asia and the Caucasus: Ten Years after Independence," Southeast European and Black Sea Studies, Vol. 1, No. 2, 2001.

Isachenko, Daria, Turkey-Russia Partnership in the War over Nagorno-Karabakh, German Institute for International and Security Affairs, Berlin, 2020.

Jenkins, Gareth H., Occasional Allies, Enduring Rivals: Turkey's Relations with Iran. Central Asia-Caucasus Institute \& Silk Road Studies Program, Washington, D. C., 2012.

Yalçınkaya, Haldun, Turkey's Overlooked Role in the Second Nagorno-Karabakh War, German Marshall Fund of the United States, January 21, 2021, Internet: https://www.gmfus.org/publications/turkeys-overlooked-role-secondnagorno-karabakh-war

Karamzadi, Moslem, Khansari Fahimeh, Fard, Explaining the Contexts of the Convergence in the Relations between Iran and the Republic of Azerbaijan and its Challenges (from 1991 to 2014), Central Eurasian Studies, Volume 10, Issue 1, 2016.

Larrabee, Stephen F., Turkey as a U.S. Security Partner, Rand Corporation, Santa Monica, California 2008. 
Larrabee, Stephan F., Lesser, Ian O., Turkish Foreign Policy in an Age of Uncertainty: RAND Corporation, Santa Monica, CA 2003.

Military Balance 2014-2019, The International Institute for Strategic Studies

Paula, Sandrin, Turkish Foreign Policy after the End of Cold War From Securitizing to Desecuritizing Actor, Turkish Policy Quarterly (TPQ), 2009, p. 6, Internet: www.turkishpolicy.com/article/116/turkeyand-caucasus-at-the-edge-of-euandnatoenlargement

Robins, Philip, Suits and Uniforms: Turkish Foreign Policy since the Cold War, Hurst \& Co., London, 2003.

Rohozinski, Jerzy, Azerbaijan and Turkey: The Light and Shade of 'Turkish' brotherhood, In: Turcja after the Start of Negotiations with the European Union - Foreign Relations and the Domestic Situation, CES Report, Warsaw, 2008.

Shiriyev, Zaur, Tkeshelashvili, Eka, Celikpala, Mitat, Institutionalizing a Trilateral Strategic Partnership: Azerbaijan, Georgia, Turkey, Policy Paper, Konrad Adenauer Stiftung, 2016.

Turkish Development Assistance Report 2014-2019, Internet, https://www.tika. gov.tr/en/publication/list/turkish_development_assistance_reports-24

Wezeman, Pieter D., Kuimova, Alexandra, Smith Jordan, Arms transfers to conflict zones: The case of Nagorno-Karabakh, Stockholm International Peace, 30 April 2021, Internet: https://www.sipri.org/commentary/topicalbackgrounder/2021/arms-transfers-conflict-zones-case-nagorno-karabakh

Winrow, Gareth, "Turkish Policy in Central Asia," in Alan Makovsky, Sabri Sayarı(eds), Turkey's New World: Changing Dynamics in Turkish Foreign Policy, Washington Institute of Near East Policy, Washington, D. C., 2000. 


\title{
THE ROLE AND SIGNIFICANCE OF TURKEY IN RELATIONS BETWEEN ARMENIA AND AZERBAIJAN
}

\begin{abstract}
The fifteen former Soviet republics represent a very diverse group of states with uneven economic development, diverse demographic, ethnic and religious structures. In such circumstances, Turkey, which geographically belongs to both Europe and Asia, sought a way to achieve its foreign policy priorities and changed the way the foreign policy was conducted in the post-Soviet space. Armenia's dispute with Turkey is historical and refers to the non-recognition of the genocide against Armenians by Turkey in the First World War. On the other hand, Azerbaijan is very similar in its specifics to the "Asian pragmatist" countries (Turkmenistan, Tajikistan and Uzbekistan), which are oriented towards building pragmatic relations with their "big neighbors", but at the same time, it is increasingly turning towards Turkey. In the conflicts around Nagorno-Karabakh, Turkey wants to create a counterweight to Armenia's allies, but also to strengthen its status as a regional power.

Historically, in relations in the post-Soviet space, Turkey used its soft power, which was primarily based on national culture, political values, religion, economy, institutions and foreign policy. However, it is obvious that soft power was not enough in the changed regional security circumstances, which is why Turkey started using hard power (army) again to strengthen its leadership position. Following the doctrine of "strategic depth", under the influence of the policy of improving relations with neighbors and neo-Ottomanism, Turkey followed the path of advocating Western policies towards independence and influence in the regions of the South Caucasus and Karabakh in search of its national interests.
\end{abstract}

Keywords: Turkey, Nagorno-Karabakh, soft power, armed conflict, use of force, strategic depth. 